Original Article

\title{
The Effect of Methanolic Extract and Ethyl Acetate Fraction of Kepel Fruit (Stelechocarpus burahol) to a-Glutathione S-Transferase Enzyme Concentration of Rat Liver and Blood Induced by $\mathrm{CCl}_{4}$
}

\section{Pengaruh Ekstrak Metanolik dan Fraksi Etil Asetat Buah Kepel (Stelechocarpus burahol) terhadap Konsentrasi Enzim $\alpha$-Glutation S-Transferase Hepar dan Darah Tikus yang diinduksi $\mathrm{CCl}_{4}$}

\author{
Yusuf Rabbani ${ }^{1 *}$, Claude Mona Airin ${ }^{2}$, Sugeng Riyanto ${ }^{1,3}$ \\ ${ }^{1}$ Fakultas Farmasi, Universitas Gadjah Mada Yogyakarta, 55281 Indonesia \\ ${ }^{2}$ Departemen Anatomi dan Fisiologi Hewan, Fakultas Kedokteran Hewan, Universitas Gadjah Mada, Indonesia \\ ${ }^{3}$ Departemen Kimia Farmasi, Fakultas Farmasi, Universitas Gadjah Mada Yogyakarta, 55281 Indonesia \\ *Corresponding author: Yusuf Rabbani I Email: yusufrabbani36@gmail.com
}

Received: 1 July 2020; Revised: 30 August 2020; Accepted: 5 September 2020; Published: 26 October 2020

\begin{abstract}
Degenerative diseases are mostly cause by high free radical concentrations in the body. Kepel fruit (Stelechocarpus burahol) is known to contain flavonoid compounds, a class of compounds that has free radical scavenging activity in the body and could affect the activity of antioxidant enzymes. There have been reports that methanolic extract and ethyl acetate fractions of Kepel fruit have the lowest IC50 values, compared to extracts or fractions which are made using other organic solvents, on in vitro assays so that flavonoids are suspected as responsible compounds to the free radical scavenging activity. This study aimed to identify the presence of flavonoid content in methanolic extract and the fraction of ethyl acetate of Kepel fruit and also its effect on rat alpha Glutathione S-Transferase ( $\alpha$-GST) enzyme concentration for the function to prevent hepatic cell damage due to carbon tetrachloride exposure. The identification of flavonoids content used a series of color chemical reaction tests and thin layer chromatography that used silica gel $60 \mathrm{~F}_{254}$ as the solid phase and mixture of ethyl acetate, formic acid, glacial acetic acid, and water (100: $11: 11: 20 \mathrm{v} / \mathrm{v}$ ) as the mobile phase. This study used 30 Sprague-Dawley female rats (age 2-3 months) that were grouped into 5 groups as solvent control (CMC-Na) group, negative control $\left(\mathrm{CCl}_{4}\right)$ group, positive control (vitamin $\left.\mathrm{C}\right)$ group, methanolic extract group, and ethyl acetate fraction group. All groups were induced with carbon tetrachloride $\left(\mathrm{CCl}_{4}\right)$ compounds except for the CMC-Na solvent control group. Blood sampling at $0 \mathrm{~h}, 24 \mathrm{~h}$, and $72 \mathrm{~h}$, while liver sampling at 24 $\mathrm{h}$ and $72 \mathrm{~h}$, with 3 samples each group. The analysis of rat $\alpha$-GST enzyme concentrations used the Enzyme-linked Immunosorbent Assay (ELISA) method. Based on the phytochemical test, the methanolic extract and the ethyl acetate fraction of Kepel fruit have been identified contains flavonoids compound. Based on the in vivo study, the positive control group's $\alpha$-GST enzyme concentration was decreased, while the negative control group's $\alpha$-GST enzyme concentration was increased. Administration of methanolic extract and ethyl acetate fraction also decreased both liver and blood rat $\alpha$-GST enzyme concentrations, although without significant correlation, and still could prevent the hepatic cell damage due to carbon tetrachloride exposure.
\end{abstract}

Keywords: Methanolic extract of Kepel fruit; Ethyl acetate fraction of Kepel fruit; Flavonoid; $\alpha$-GST enzyme concentration 
Abstrak: Penyakit degeneratif banyak disebabkan oleh adanya radikal bebas dengan konsentrasi di atas normal. Buah kepel (Stelechocarpus burahol) diketahui mengandung senyawa flavonoid yang diketahui memiliki aktivitas penangkapan radikal bebas di dalam tubuh dan mempengaruhi aktivitas enzim antioksidan. Penelitian ini bertujuan mengidentifikasi adanya kandungan flavonoid dalam ekstrak metanolik dan fraksi etil asetat buah kepel serta mempelajari pengaruhnya terhadap konsentrasi enzim $\alpha$-Glutathione $S$-Transferase ( $\alpha$-GST) tikus dalam kaitannya dengan pencegahan kerusakan sel hepar akibat paparan karbon tetraklorida. Identifikasi adanya flavonoid diuji menggunakan uji reaksi kimia warna dan uji kromatografi lapis tipis dengan fase diam silika gel 60F254 dan fase gerak berkomposisi etil asetat, asam format, asam asetat glasial, dan air (100: $11: 11: 20 \mathrm{v} / \mathrm{v})$. Pengujian secara in vivo pada penelitian ini menggunakan tikus galur Sprague-Dawley betina (umur 2-3 bulan) sebanyak 30 ekor yang dikelompokkan menjadi 5 kelompok, yaitu kelompok kontrol pelarut (CMC-Na), kontrol negatif $\left(\mathrm{CCl}_{4}\right)$, kontrol positif (vitamin $\left.\mathrm{C}\right)$, pemberian ekstrak metanolik dan pemberian fraksi etil asetat. Semua kelompok tikus diinduksi dengan senyawa karbon tetraklorida $\left(\mathrm{CCl}_{4}\right)$ kecuali kelompok kontrol pelarut CMC-Na. Pengambilan sampel darah pada waktu jam ke-0, ke-24, dan ke-72, sedangkan pengambilan sampel hepar pada waktu jam ke-24 dan ke-72, dengan masing-masing kelompok 3 sampel. Analisis konsentrasi enzim $\alpha$-GST pada tikus menggunakan metode Enzyme-linked Immunosorbent Assay (ELISA). Melalui uji fitokimia, teridentifikasi bahwa terdapat kandungan senyawa flavonoid dalam fraksi ekstrak metanolik dan etil asetat buah kepel. Penurunan konsentrasi enzim $\alpha$-GST terjadi pada kelompok tikus dengan pemberian vitamin C dan peningkatan konsentrasi enzim $\alpha$-GST terjadi pada kelompok tikus dengan pemberian $\mathrm{CCl}_{4}$. Pemberian ekstrak metanolik dan fraksi etil asetat juga menunjukkan penurunan konsentrasi enzim $\alpha$-GST baik hepar maupun darah tikus yang terinduksi $\mathrm{CCl}_{4}$, meskipun tidak ditemukan korelasi yang nyata antara konsentrasi enzim $\alpha$-GST di hepar dan di darah, serta tetap dapat mencegah kerusakan sel hepar akibat paparan $\mathrm{CCl}_{4}$.

Kata kunci: Ekstrak metanolik buah kepel; Fraksi etil asetat buah kepel; Flavonoid; Konsentrasi enzim $\alpha$-GST

\section{PENDAHULUAN}

Salah satu permasalahan yang meresahkan masyarakat kini adalah penyakit-penyakit kronis dan degeneratif seperti kanker, penuaan, hingga penyakit kardiovaskuler yang salah satu penyebabnya karena banyaknya radikal bebas dalam tubuh. Radikal bebas secara alami dibentuk oleh tubuh, dalam konsentrasi rendah berfungsi sebagai imunitas, namun dalam konsentrasi tinggi justru memicu kerusakan seluler [1-2].

Tubuh manusia memiliki mekanisme untuk mengatasi stress oksidatif dengan adanya senyawa antioksidan. Antioksidan berperan menghambat oksidasi dari molekul senyawa lain, dengan menetralisir radikal bebas berlebih [3-4]. Antioksidan dapat diperoleh dari asupan makanan, antioksidan sintetik maupun antioksidan alami. Antioksidan alami banyak dikembangkan karena kekhawatiran dari masyarakat akan efek samping antioksidan sintetik. Studi menunjukkan bahwa bahan alam yang mengandung senyawa fenolik seperti flavonoid memiliki aktivitas antioksidan sebagai penangkap radikal bebas, mempengaruhi aktivitas enzim antioksidan, dan dapat digunakan untuk terapi terhadap penyakit yang terkait radikal bebas [5-6].

Penelitian terkini menginformasikan bahwa buah tanaman kepel (Stelechocarpus burahol) memiliki kandungan senyawa antioksidan. Bagian tanaman kepel yang diketahui memiliki aktivitas antioksidan tertinggi adalah bunga dengan ekstraksi n-butanol dan buah dengan ekstraksi etil asetat [3]. Telah dilaporkan pula dalam daging buah kepel terdapat senyawa fenolik 
yang bertindak sebagai senyawa antioksidan [7]. Sejauh ini belum pernah dilakukan penelitian untuk menguji aktivitas antioksidan ekstrak metanolik dan fraksi etil asetat buah kepel secara in vivo. Salah satu metode yang valid untuk menentukan potensi antioksidan adalah dengan mengukur aktivitas enzim glutathione s-transferase (GST) khususnya tipe alpha ( $\alpha$-GST). Kerusakan sel akibat senyawa radikal bebas akan direspon tubuh dengan membentuk enzim tersebut sehingga konsentrasinya akan meningkat. Perubahan konsentrasi konsentrasi enzim $\alpha$-GST dapat dijadikan parameter untuk mengidentifikasi aktivitas antioksidan dari suatu senyawa eksogen untuk menetralkan radikal bebas. Maka dari itu, dalam penelitian ini akan diidentifikasi aktivitas penetralan radikal bebas oleh ekstrak metanolik dan fraksi etil asetat buah kepel secara in vivo pada hewan uji dengan parameter konsentrasi enzim $\alpha$-GST.

\section{BAHAN DAN METODE}

\subsection{Bahan}

Sampel buah kepel diperoleh dari Kecamatan Seyegan, Kabupaten Sleman, DIY; metanol (teknis), etil asetat, diklorometan, dan natrium sulfat anhidrat (Merck, untuk analisis EMSURE@ sesuai ICS, ISO atau Reag. PhEur.), petroleum eter (Merck, untuk analisis EMSURE® sesuai ICS, ISO, titik didih $40-60^{\circ} \mathrm{C}$ ), lempeng silika gel $60 \mathrm{~F} 254$ (Merck, 20x20 cm), rutin hidrat dan kuersetin dihidrat (Sigma), asam borat, asam asetat glasial, asam format, dan metanol (Merck, untuk analisis EMSURE@ sesuai ICS, ISO atau Reag. Ph Eur.), FeCl3 (Merck, pro analys), asam oksalat (Baker Chemical, Baker Analyzed Reagent), tikus betina Strain Sprague-Dawley (2-3 bulan) yang sehat dengan bobot 100-160 gram sebanyak 40 ekor, senyawa antioksidan alami vitamin C (MKR Chemical, food grade), $\mathrm{CCl}_{4}$ (Merck), $\mathrm{CMC}-\mathrm{Na}$ (Bratachem), homogenat hepar tikus uji yang mengandung $\alpha$-GST, olive oil (Boiges, grade extra virgin olive oil), $\mathrm{NaCl} 0,9 \%$ (Otsu-NS), Fine Test Rat $\alpha$-GST ( $\alpha$-Gluthatione S-Transferases) ELISA Kit, deionized water (Onelab Waterone®), dan buffer fosfat salin $\mathrm{pH} 7,5$.

\subsection{Alat}

Alat yang digunakan adalah sentrifugator (Microcentrifuge MPW-55), neraca analitik elektrik (Analytical Balances HR-250AZ spesifikasi berat minimal 0,1 mg dan kapasitas maksimal 252 g; Mettler Toledo ME204E spesifikasi kepekaan 0,1 mg dan kapasitas maksimal $220 \mathrm{~g}$ ), vacuum rotary evaporator (Yamato, tipe RE 310), lampu UV $254 \mathrm{~nm}$ dan $366 \mathrm{~nm}$, mikropipet (Socorex volume 100-1000 (L; Gilson Pipetman volume 20-200/L), microplate reader (Bio-Rad 680 XR), disposable tip, microtube, conical tube, incubator $37^{\circ} \mathrm{C}$, microhematocrit non-heparin tube, alat-alat bedah, dan alat-alat gelas yang lazim digunakan pada laboratorium kimia analisis.

\subsection{Metode ekstraksi dan fraksinasi buah kepel}

Metode ekstraksi dan fraksinasi buah kepel mengacu pada Batubara et al. [8]. Buah kepel segar yang telah dihaluskan dimaserasi dengan metanol (1:2) dengan dilanjutkan 1 kali remaserasi. Maserasi dilakukan selama 3 hari dengan pengadukan setiap hari. Remaserasi dengan total volume metanol yang sama dilakukan selama 3 hari, dengan pengadukan setiap hari. Setelah maserasi selesai, dilakukan penguapan menggunakan vaccum rotary evaporator untuk mendapatkan ekstrak buah kepel. Ekstrak buah kepel kemudian difraksinasi secara bertingkat menggunakan pelarut petroleum eter, diklorometan, dan etil asetat.

\subsection{Uji fitokimia}

Uji fitokimia kandungan senyawa fenolik dan flavonoid dilakukan dengan uji reaksi kimia warna maupun uji kromatografi lapis tipis (KLT). Uji reaksi kimia warna menggunakan prosedur 
yang termuat dalam buku Methods in Biotechnology [9]. Identifikasi senyawa polifenol menggunakan reagen $\mathrm{FeCl} 35 \%$ yang ditandai dengan terbentuknya endapan warna cokelat. Identifikasi senyawa flavonoid menggunakan asam sulfat yang ditandai dengan terbentuknya warna kunig, merah kebiruan, atau oranye-merah. Identifikasi senyawa glikosida flavonoid menggunakan reagen Taubock yang ditandai dengan fluoresensi apabila diamati pada UV 366 . Uji kromatografi lapis tipis (KLT) didasarkan pada Wagner dan Bladt [10] menggunakan fase diam plat silika gel $60 \mathrm{~F}_{254}$ dan dielusi dengan eluen campuran etil asetat : asam format : asam asetat glasial : air (100: $11: 11: 20$ ). Plat yang telah dielusi diuapi dengan ammonia pekat, disemprot dengan reagen sitroborat, kemudian diamati dibawah sinar tampak, UV 254, dan UV 366 .

\subsection{Perlakuan hewan uji}

Perlakuan hewan uji dilakukan sebagaimana dalam Singh et al. [11] dengan penyesuaian. Tikus betina muda (Strain Sprague-Dawley dengan umur 2-3 bulan dan berat 100-160 gram) diperoleh dari Unit Pengembangan Hewan Percobaan (UPHP) Laboratorium Penelitian dan Pengujian Terpadu (LPPT) UGM, dipelihara dalam kondisi yang dipertahankan pada suhu $25 \pm$ $2^{\circ} \mathrm{C}$ dengan humiditas relatif $70-90 \%$ dan siklus gelap/terang selama 12 jam. Tikus uji ditempatkan pada kandang ukuran $42 \times 21 \times 20 \mathrm{~cm}(\mathrm{p} \times 1 \times \mathrm{t})$ dan diberi pakan AD II dan minum air RO ad libitum. Pengujian kemampuan ekstrak/fraksi buah kepel sebagai antioksidan dalam mencegah kerusakan sel hepar yang bersifat akut dilakukan pada tikus dengan paparan CCL4. Tikus sebanyak 40 ekor dibagi menjadi 8 kelompok perlakuan dengan masing-masing kelompok berisi 8 ekor. Kelompok I adalah kelompok kontrol pelarut CMCNa 0,1\% secara per oral sebanyak $1 \mathrm{~mL}$. Kelompok II sebagai kontrol positif, diberi vitamin C (antioksidan sintesis) dengan dosis sebesar $200 \mathrm{mg} / \mathrm{kgBB}$ secara peroral. Kelompok III sebagai kontrol negatif, hanya diinduksi $\mathrm{CCl}_{4}$ dengan dosis $1,5 \mathrm{~mL} / \mathrm{kgBB}$. Kelompok IV diberi ekstrak metanolik buah kepel, dan kelompok V diberi fraksi etil asetat buah kepel. Pengambilan darah pada plexus retroorbitalis dilakukan pada jam ke-0, ke-24 dan ke-72 sebanyak 1,5 mL untuk masing-masing waktu pengambilan 3 sampel/tikus tiap kelompok. Tikus uji pada jam ke-24 dan ke-72 dikorbankan dan diambil organ heparnya, untuk masing-masing waktu pengambilan 3 sampel/tikus tiap kelompok.

Pengukuran berat relatif organ hepar tikus uji dilakukan sebagaimana Halim et al. [12]. Setiap hepar yang telah diambil dibersihkan dahulu dari lemak yang tampak dan kemudian ditimbang berat absolut. Berat relatif organ (BRO) dari tiap hepar dihitung menggunakan persamaan berikut:

$$
B R O=\frac{\text { berat hepar tikus }(g)}{\text { berat tikus saat dikorbankan }(g)} \times 100
$$

\subsection{Preparasi sampel}

Proses preparasi serum darah dan hepar tikus dilakukan sebagaimana protokol langkah kerja pada Fine Test Rat $\alpha$-GST ( $\alpha$-Glutathione S-Transferases) ELISA Kit [13]. Serum darah diperoleh dengan cara sampel dibiarkan selama 2 jam pada suhu ruang $\left(27^{\circ} \mathrm{C}\right)$ kemudian disentrifugasi selama 20 menit dengan kecepatan 1000xg. Supernatan diambil dan dimasukkan dalam microtube, serta disimpan pada suhu $-80^{\circ} \mathrm{C}$. Untuk memperoleh homogenate hepar yang mengandung enzim $\alpha$-GST dari hepar tikus, hepar dicuci terlebih dahulu dengan Phosphate Buffer Saline (PBS) dingin (0,01 M, pH 7,4). Hepar ditimbang 1 gram dan dihancurkan, kemudian dihomogenkan dalam $2 \mathrm{~mL}$ PBS. Homogenat disentrifugasi selama 30 menit dengan kecepatan 
10.000xg dalam suhu $4^{\circ} \mathrm{C}$. Supernatan diambil dan dimasukkan dalam tube, serta disimpan pada suhu $-80^{\circ} \mathrm{C}$.

\subsection{Pengukuran konsentrasi enzim $\alpha$-GST tikus}

Konsentrasi enzim $\alpha$-GST serum darah dan hepar tikus diukur menggunakan Fine Test Rat $\alpha$-GST ( $\alpha$-Glutathione S-Transferases) ELISA Kit. Prinsip pengukuran konsentrasi enzim $\alpha$-GST tikus ini sesuai dengan metode sandwich enzyme-linked immunosorbent assay, dimana 96-well plate telah dilapisi oleh anti- $\alpha$-GST antibodi. Biotin terkonjugasi anti- $\alpha$-GST antibodi digunakan untuk deteksi. Larutan standar, sampel, dan biotin terkonjugasi anti- $\alpha$-GST ditambahkan pada wells setelahnya, dan kemudian dicuci dengan buffer. HRP-Streptavidin ditambahkan, lalu konjugat yang tak berikatan akan hilang bersama pencucian dengan buffer. Substrat TMB ditambahkan pada wells dimana TMB akan dikatalisis oleh HRP untuk menghasilkan produk berwarna biru yang kemudian berubah menjadi kuning setelah diberikan acidic stop solution. Densitas warna kuning proporsional dengan jumlah $\alpha$-GST dalam plate. Densitas optik (O.D.) dibaca pada panjang gelombang $450 \mathrm{~nm}$ menggunakan microplate reader sehingga konsentrasi $\alpha$-GST dapat dikalkulasikan. Metode ini memiliki spesifisitas yang tinggi untuk enzim $\alpha$-GST tanpa cross-reactivity atau gangguan yang signifikan dari senyawa analog $\alpha$-GST [13].

\subsection{Metode analisis}

Data uji kualitatif pada uji tabung berupa data reaksi kimia warna, sedangkan data kualitatif KLT berupa adanya bercak yang diamati pada sinar tampak, UV 254 , dan UV 366 . Bercak berfluoresensi kuning, hijau, atau biru di bawah UV 366 menunjukkan adanya kandungan flavonoid pada ekstrak metanolik dan fraksi etil asetat. Bila nilai Rf dari sampel dan pembanding (rutin dan kuersetin) sama maka dapat dinyatakan terdapat kandungan senyawa rutin dan/atau kuersetin pada sampel. Bila nilai Rf sampel dan pembanding tidak sama, maka ada kemungkinan flavonoid jenis lain.

Data penimbangan bobot hepar tikus dalam satuan nilai gram (g) dan berat relatif organ hepar dihitung menggunakan persamaan yang telah tertera. Data berat relatif organ disajikan dalam bentuk rata-rata \pm simpangan baku (SD). Data konsentrasi enzim $\alpha$-GST dalam satuan nilai $\mathrm{pg} / \mathrm{mL}$. Perhitungan nilai konsentrasi enzim $\alpha$-GST menggunakan persamaan kurva baku yang telah memenuhi kriteria validitas.

Uji signifikansi antar data kuantitatif satu kelompok perlakuan dengan kelompok perlakuan lain (tiap jenis data) menggunakan aplikasi Statistical Program Service Solution (IBM SPSS Statistics versi 19) dengan taraf kepercayaan 95\%. Uji normalitas menggunakan uji Shapiro-Wilk karena jumlah data tiap kelompok tidak lebih dari 50. Uji signifikansi parametrik antar 2 kelompok menggunakan uji independent sample t-test dan bila non-parametrik menggunakan uji Mann-Whitney. Uji signifikansi antar $>2$ kelompok didahului dengan uji homogenitas. Uji signifikansi parametrik (data terdistribusi normal dan homogen) menggunakan uji One-Way ANOVA yang dilanjutkan uji Post Hoc (membandingkan antar 2 kelompok) dengan metode Tukey dan LSD bila ANOVA menyatakan berbeda signifikan. Uji signifikansi non-parametrik menggunakan Kruskal-Wallis. Uji korelasi parametrik antar 2 kelompok data menggunakan uji Pearson dan non-parametrik menggunakan uji Kendall's tau. 


\section{HASIL DAN PEMBAHASAN}

\subsection{Hasil ekstraksi dan fraksinasi}

Bagian tanaman yang digunakan dalam penelitian ini adalah buah kepel yang diperoleh dari Kecamatan Seyegan, Kabupaten Sleman, DIY. Ekstrak yang diperoleh mempunyai ciri organoleptik berwarna cokelat tua dengan bau khas. Rendemen ekstrak metanol yang diperoleh sebanyak $0,81 \%$, sedangkan rendemen fraksi etil asetat didapatkan sebanyak $0,3 \%$. Tahap fraksinasi dilakukan menganut prinsip ekstraksi cair-cair dimana terjadi kontak antar dua pelarut yang tidak saling bercampur sehingga akan terbentuk 2 fase. Hal ini menyebabkan terjadinya perpindahan massa senyawa dengan kelarutan yang sesuai dari pelarut asal ke pelarut pengekstraksi [14]. Fraksinasi menggunakan petroleum eter dan diklorometan akan menarik senyawa-senyawa yang cenderung non-polar sehingga fraksi etil asetat akan mengandung senyawa relatif lebih polar. Ekstrak metanolik dapat mengandung lebih banyak senyawa karena penyari alkoholik dapat menyari senyawa lain selain fenolik, atau dalam hal ini flavonoid. Gula seperti glukosa, fruktosa, dan sukrosa kemungkinan ada dalam ekstrak karena masih dapat terlarut metanol baik dalam bentuk glikosida maupun gula bebas [15].

\subsection{Uji fitokimia}

Uji fitokimia dilakukan dengan uji reaksi kimia terhadap reagen dan uji kromatografi lapis tipis (KLT) untuk mengidentifikasi adanya kandungan senyawa flavonoid atau fenolik yang terdapat dalam ekstrak metanolik dan fraksi etil asetat buah kepel. Uji pendahuluan dilakukan dengan menggunakan reagen $\mathrm{FeCl}_{3}$ untuk mendeteksi adanya polifenol. Pengujian menggunakan metode Taubock ditujukan untuk identifikasi adanya glikosida flavonoid sehingga terbentuk larutan yang berfluoresensi [16]. Senyawa asam sulfat digunakan untuk mengidentifikasi jenis golongan senyawa flavonoid [17]. Hasil identifikasi senyawa dapat dilihat pada Tabel 1.

Tabel 1. Hasil identifikasi senyawa berdasarkan uji reaksi kimia

\begin{tabular}{llll}
\hline & Polifenol & Glikosida Flavonoid & Flavonoid \\
\hline Ekstrak Metanolik & + & - & $+^{*}$ \\
Fraksi Etil Asetat & + & + & $+^{* *}$ \\
\hline
\end{tabular}

Keterangan: *berwarna cokelat gelap; **berwarna cokelat

Pada penambahan reagen $\mathrm{FeCl}_{3}$, ekstrak metanolik berubah warna menjadi cokelat gelap sedangkan fraksi etil asetat berubah menjadi cokelat gelap kehijauan. Pada dasarnya akan terjadi perubahan warna menjadi biru gelap atau biru gelap kehijauan bila ada polifenol [17]. Namun, karena warna awal dari sampel adalah kecokelatan maka akan terbentuk warna cenderung cokelat. Kedua sampel dapat dinyatakan mengandung senyawa polifenol, meskipun keberadaan tannin atau fenolik lain bisa berpengaruh sehingga dapat terjadi false positive. Pada pengujian menggunakan reagen Taubock, hanya pada fraksi etil asetat yang terbentuk fluoresensi yang berarti terdapat kandungan glikosida flavonoid.

Pengujian menggunakan $\mathrm{H}_{2} \mathrm{SO}_{4}$ pekat bertujuan untuk mengetahui jenis/golongan flavonoid. Sampel fraksi etil asetat membentuk cairan berwarna cokelat yang lebih terang, perubahan warna ini dapat menunjukkan adanya kandungan flavon dan flavonol dimana warna kuning jika bercampur dengan warna awal cokelat maka hanya akan menambah intensitas warna cokelat. Sampel ekstrak metanolik, terbentuk cairan berwarna cokelat gelap yang dapat 
disebabkan karena kandungan senyawa flavonoid golongan lain yang pada dasarnya akan memberikan warna merah atau merah kebiruan [17].

Uji KLT dilakukan dengan menggunakan pembanding rutin dan kuersetin. Pereaksi yang digunakan pada uji KLT adalah uap ammonia dan sitroborat. Profil kromatogram ekstrak metanolik dan fraksi etil asetat buah kepel dapat dilihat pada Gambar 1. dan nilai Rf hasil pengamatan dapat dilihat pada Tabel 2.

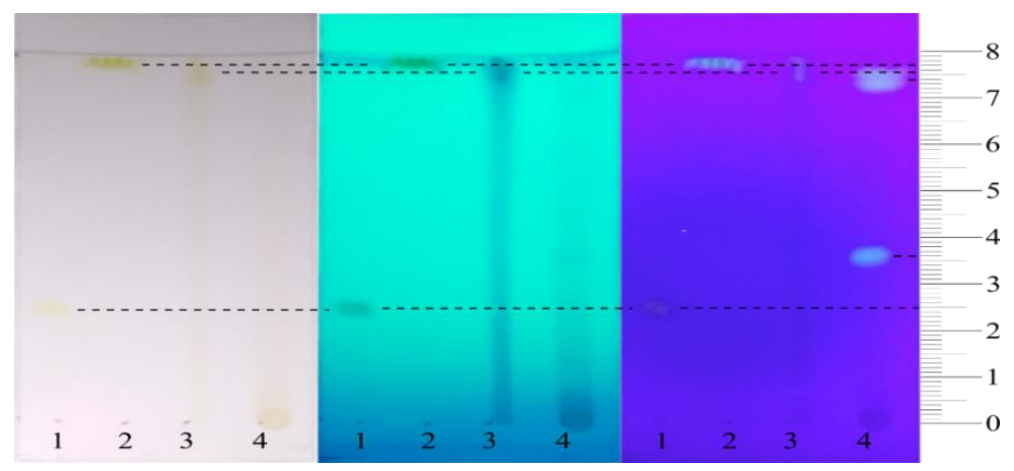

Gambar 1. Profil kromatogram ekstrak metanolik dan fraksi etil asetat buah kepel. Secara berturut dari kiri pengamatan di bawah sinar tampak, di bawah UV254, dan di bawah UV366. Keterangan: (1) Rutin, (2) Kuersetin, (3) Ekstrak metanolik buah kepel, dan (4) Fraksi etil asetat buah kepel.

Tabel 2. Hasil pengamatan bercak pada kromatogram

\begin{tabular}{ccccc}
\hline & Rf & Sinar tampak & $\mathbf{U V}_{254}$ & UV $_{366}$ \\
\hline Rutin & 0,29 & Cokelat pudar & Abu-abu pudar & Biru gelap \\
Kuersetin & 0,98 & Cokelat & Cokelat & Biru terang \\
Ekstrak Metanolik & 0,96 & Cokelat pudar & Abu-abu & Biru pudar \\
Fraksi Etil Asetat & 0,45 & - & - & Biru terang \\
& 0,93 & - & - & Biru pucat \\
\hline
\end{tabular}

Rutin tampak pada nilai Rf 0,29 meredam di bawah sinar $\mathrm{UV}_{254}$ dan sedikit berfluoresensi di bawah UV 366 . Kuersetin tampak pada nilai Rf 0,98 dimana di bawah UV 254 meredam dengan kecenderungan berwarna cokelat dan berfluoresensi di bawah UV $\mathrm{U}_{366}$. Ekstrak metanolik buah kepel tampak meredam di bawah $\mathrm{UV}_{254}$ dengan nilai Rf 0,96 dan pada nilai Rf yang sama berfluoresensi di bawah UV 366 . Fraksi etil asetat berfluoresensi cukup intens di bawah UV 366 pada Rf 0,45 dan 0,93 meskipun pada pengamatan di bawah $\mathrm{UV}_{254}$ tidak terdapat bercak yang meredam fluoresensi. Senyawa flavonoid dalam fraksi etil asetat yang ditunjukkan pada Rf 0,45 dapat dikatakan memiliki struktur yang berbeda dengan senyawa rutin, dimana bersifat relatif non-polar terhadap rutin yang mengikat 2 glikosida. Meskipun demikian, sifat kepolarannya juga berbeda cukup jauh (lebih polar) dibanding kuersetin sehingga boleh jadi merupakan flavonoid monoglikosida atau glikosida lain yang lebih non-polar dibanding rutin. Hal ini diperkuat dengan literatur Pramono [18], dimana pelarut etil asetat dapat melarutkan flavonoid monoglikosida.

\subsection{Berat relatif hepar}

Pemaparan tikus dengan senyawa $\mathrm{CCl}_{4}$ akan menyebabkan terjadinya hepatotoksik akibat keadaan steatosis atau inflamasi. Hepar tikus baik jantan maupun betina terinduksi $\mathrm{CCl}_{4}$ akan mengalami kenaikan berat absolut maupun berat relatif organ (BRO) hepar [19]. Pada penelitian ini pengukuran berat relatif organ hepar digunakan sebagai gambaran terjadinya kerusakan pada 
hepar setelah paparan $\mathrm{CCl}_{4}$. Berat relatif hepar tikus uji dari tiap kelompok perlakuan dapat dilihat pada Tabel 3.

Tabel 3. Nilai BRO hepar rata-rata tiap kelompok tikus pada jam ke-72

\begin{tabular}{|c|c|c|c|c|c|}
\hline & $\begin{array}{l}\text { Kontrol } \\
\text { Pelarut }\end{array}$ & $\begin{array}{l}\text { Ekstrak } \\
\text { Metanolik }\end{array}$ & $\begin{array}{l}\text { Fraksi } \\
\text { Asetat }\end{array}$ & Vitamin C & $\mathrm{CCl}_{4}$ \\
\hline $\mathrm{BRO}$ & $3,82 \pm 0,20$ & $3,98 \pm 0,15$ & $3,99 \pm 0,02$ & $4,06 \pm 0,15$ & $4,64 \pm 0,12^{*}$ \\
\hline
\end{tabular}

Keterangan: nilai $\mathrm{BRO} \pm \mathrm{SD}(\mathrm{n}=3)$; *berbeda signifikan $(P<0,05)$ terhadap kelompok lain

Berdasarkan Tabel 3, dapat dinyatakan bahwa pemberian $\mathrm{CCl}_{4}$ dengan dosis $1,5 \mathrm{mg} / \mathrm{kgBB}$ mampu meningkatkan berat relatif hepar tikus secara signifikan dan mungkin terjadi kerusakan hepar tikus. Di sisi lain, nilai berat relatif hepar yang tidak berubah signifikan antara kelompok kontrol pelarut, pemberian ekstrak metanolik buah kepel (EM), pemberian fraksi etil asetat buah kepel (EA), dan pemberian vitamin $\mathrm{C}$ dapat menjadi gambaran bahwa kandungan ekstrak metanolik, fraksi etil asetat buah kepel, dan vitamin $\mathrm{C}$ memiliki kemampuan menghambat kerusakan hepar akibat paparan $\mathrm{CCl}_{4}$

\subsection{Analisis konsentrasi enzim GST}

Enzim $\alpha$-GST merupakan salah satu enzim yang bertanggungjawab dalam proses detoksifikasi seluler. Enzim ini banyak berada pada hepar, lebih khusus pada sitosol hepar [20]. Konsentrasi enzim tersebut di plasma merepresentasikan kerusakan hepar lebih baik dibanding aminotransferase [21]. Pemaparan menggunakan $\mathrm{CCl}_{4}$ akan menyebabkan kerusakan hepar dengan pembentukan radikal bebas, dimana dengan pemberian ekstrak metanolik dan fraksi etil asetat buah kepel yang dicurigai mengandung senyawa antioksidan akan menangkal radikal bebas dan menjaga hepar dari kerusakan sehingga parameter konsentrasi enzim $\alpha$-GST tetap rendah. Pengukuran konsentrasi enzim $\alpha$-GST hepar dan plasma tikus dilakukan menggunakan Fine Test Rat $\alpha$-GST ELISA Kit. Kurva baku ELISA kit tersebut dapat dilihat pada Gambar 2.

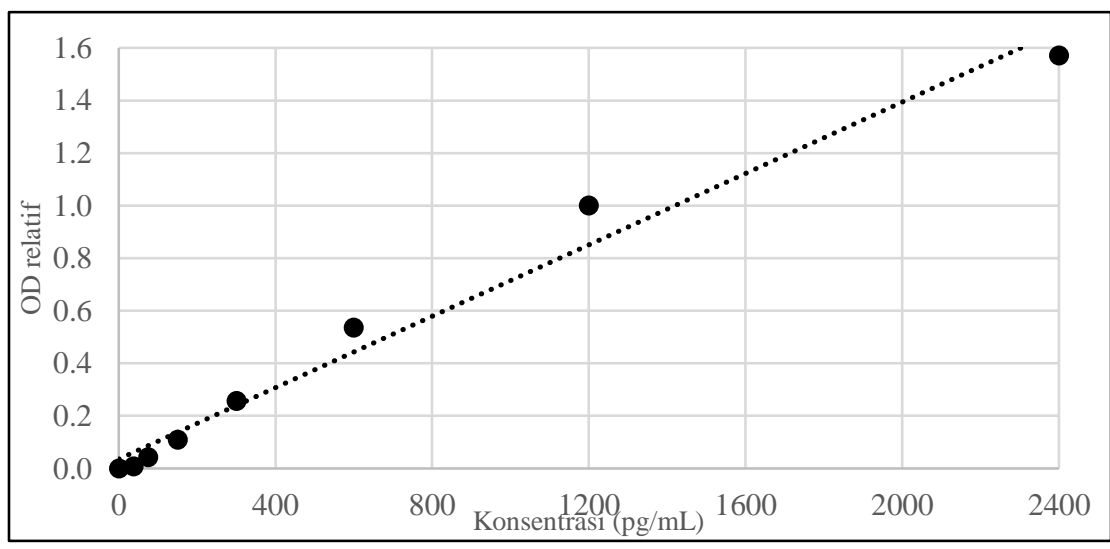

Gambar 2. Kurva baku standar enzim $\alpha$-GST tikus 
Persamaan regresi linier yang diperoleh yaitu $y=0,0007 x+0,0357$, dengan nilai $\mathrm{R}=$ 0,9896. Linearitas dari kurva baku ini telah memenuhi kriteria linearitas untuk sampel biologis dimana nilai $\mathrm{R}$ harus $>0,97$ [22]. Nilai persen recovery dari tiap konsentrasi standar berturut dari 2400 pg/mL hingga 37,5 pg/mL adalah 90,91\%; 113,96\%; 124,12\%; $119,19 \% ; 84,38 \% ; 73,52 \%$. Nilai ini telah memenuhi persyaratan nilai persen recovery metode immunoassay untuk rasio analit $10^{-9}$ yaitu antara $70-130 \%$ [23].

Peningkatan konsentrasi enzim $\alpha$-GST sebanding dengan kerusakan yang terjadi pada sel hepatosit hepar. Hasil pengukuran konsentrasi enzim $\alpha$-GST tikus uji baik pada hepar maupun darah divisualisasikan pada Gambar 3 dan Gambar 4.

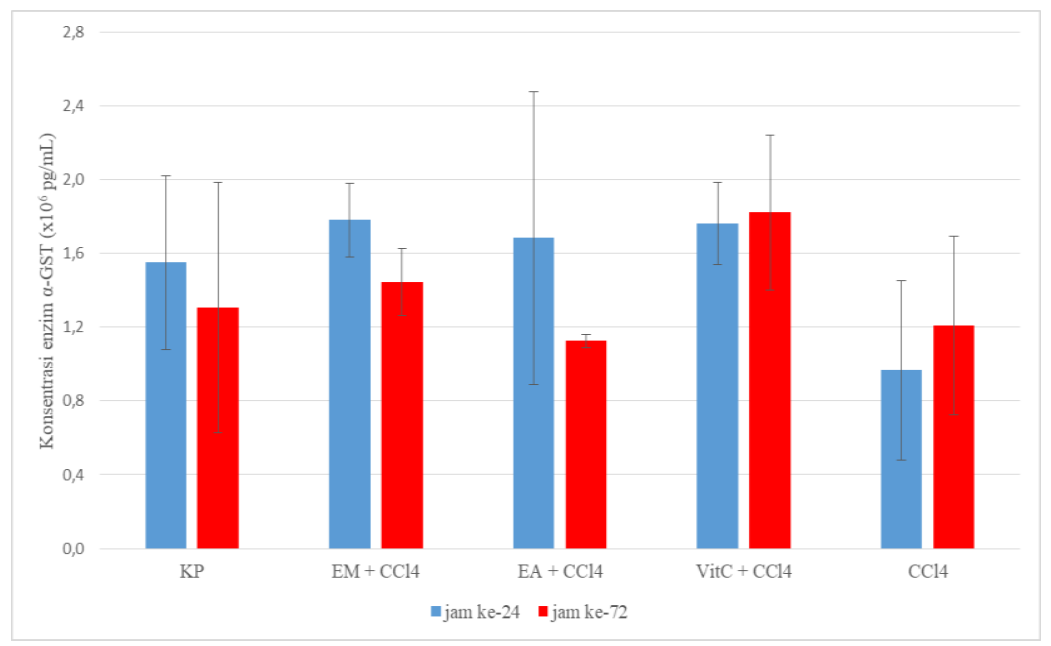

Gambar 3. Konsentrasi enzim $\alpha$-GST hepar tikus (tiap kelompok $n=3$ )

Analisis statistik menunjukkan bahwa tidak terdapat perbedaan signifikan antar kelompok perlakuan $(P>0,05)$. Meskipun demikian, apabila dibandingkan terhadap kelompok kontrol pelarut, maka kelompok EM, kelompok EA, dan kelompok vitamin $C$ cenderung memiliki konsentrasi enzim $\alpha$-GST yang lebih tinggi. Kondisi ini dapat disebabkan oleh adanya kemungkinan pengaruh dari senyawa eksogen terhadap ekspresi enzim $\alpha$-GST.

Pada sel hepatosit, terdapat faktor transkripsi Nrf2 yang berperan dalam pembentukan enzim $\alpha$-GST. Ketika tidak ada senyawa thiol-reactive elektrofil, maka Nrf2 di sitoplasma akan terikat pada protein Keap1 dan akan terproteolisis oleh 26S proteasome. Adanya senyawa elektrofil lemah ini, maka Nrf2 dapat bypass dan memasuki nukleus membentuk dimer dengan protein Maf, menempel pada antioxidant response element (ARE) dan akan mentranskripsi cDNA $\alpha$-GST sehingga terbentuk mRNA $\alpha$-GST dan pada akhirnya akan terekspresi enzim $\alpha$-GST [24]. Senyawa flavonoid atau fenolik yang ada dalam EM dan EA yang juga merupakan senyawa elektrofil lemah memungkinkan untuk beraktivitas seperti itu. Hal tersebut juga terjadi dengan adanya vitamin $C$, dimana senyawa vitamin $C$ selain sebagai penangkap radikal, dapat pula membantu meningkatkan jumlah dari mRNA $\alpha$-GST [25].

Sejumlah literatur menyatakan bahwa beberapa flavonoid juga dapat meningkatkan aktivitas enzim GST [26-27], seperti epigallocatechin gallat, epigallocatechin, procyanidin, glikosida rutin, hesperidin, naringenin, dan kuersetin [28-30]. Aktivitas dari enzim GST berkorelasi dengan konsentrasi enzim $\alpha$-GST [31]. Peningkatan jumlah atau konsentrasi enzim GST juga dapat dikatakan meningkatkan konsentrasi enzim $\alpha$-GST karena persentase konsentrasi enzim $\alpha$-GST 
2-5\% [32] sehingga pemberian ekstrak metanolik dan fraksi etil asetat diduga dapat meningkatkan konsentrasi enzim $\alpha$-GST.

Nilai konsentrasi enzim $\alpha$-GST kelompok pemberian $\mathrm{CCl}_{4}$ pada jam ke-24 lebih rendah, meskipun tidak signifikan $(P>0,05)$ dibanding kelompok kontrol pelarut. Kondisi ini kemungkinan diakibatkan telah adanya kematian sebagian sel hepatosit sehingga jumlah enzim $\alpha$-GST yang diekspresikan lebih rendah. Berdasarkan studi literatur, diketahui bahwa pemaparan $\mathrm{CCl}_{4}$ akan berdampak pada sel hepar, antara lain steatosis, nekrosis, dan induksi apoptosis [33-35]. $\mathrm{CCl}_{4}$ dapat menginduksi terjadinya apoptosis melalui jalur JNK dan mengekspresi gen pro-apoptosis seperti tumor necrosis factor- $\alpha$ (TNF- $\alpha$ ) dan Bcl2 homologous antagonist/killer (Bak) pada liver mencit terinduksi $\mathrm{CCl}_{4}[35]$.

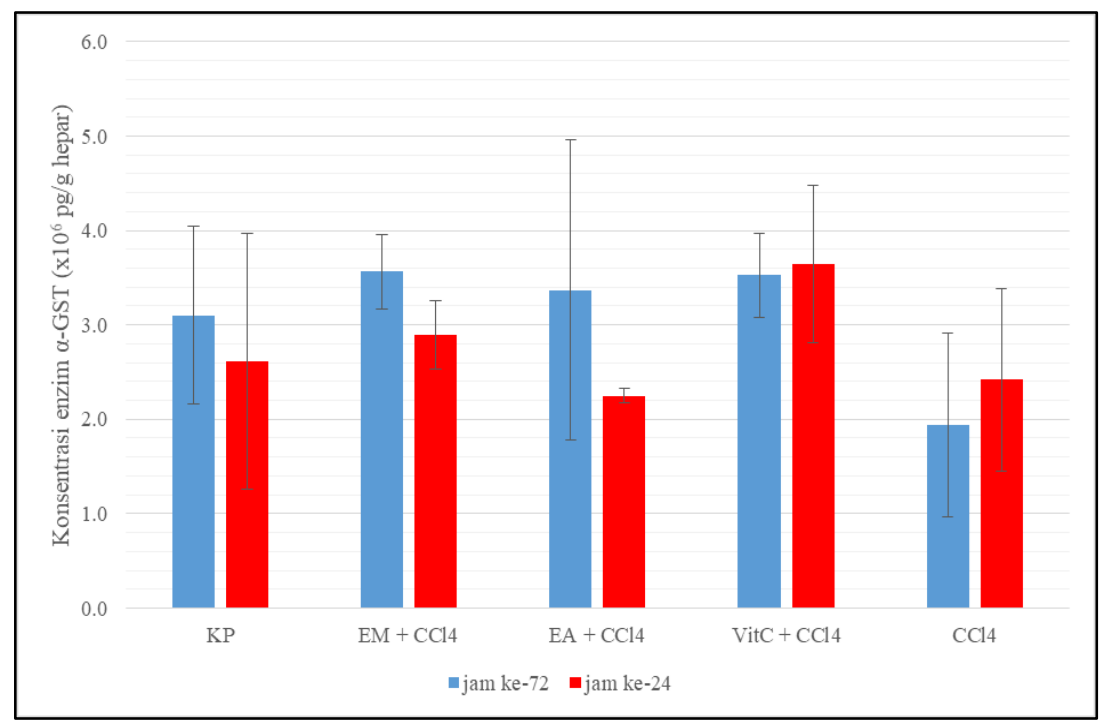

Gambar 4. Konsentrasi enzim $\alpha$-GST hepar tikus hasil konversi (tiap

Konsentrasi enzim $\alpha$-GST hepar pada jam ke-72 kelompok kontrol pelarut, kelompok EM, dan kelompok EA mengalami penurunan dibanding konsentrasi enzim $\alpha$-GST pada jam ke-24. Hal ini sesuai dengan literatur dimana efek toksik $\mathrm{CCl}_{4}$ akan berkurang pada jam ke-72 setelah pemejanan karena telah tereliminasi sehingga ekspresi enzim $\alpha$-GST berkurang [36-37].

Konsentrasi enzim $\alpha$-GST pada jam ke-72 kelompok $\mathrm{CCl}_{4}$ dan kelompok vitamin $\mathrm{C}$ terjadi kenaikan meskipun tidak signifikan $(P>0,05)$ terhadap konsentrasi enzim $\alpha$-GST jam ke-24. Sel hepar pada dasarnya merupakan sel dengan regenerasi yang cepat, dimana dapat beregenerasi dalam kisaran waktu 48 jam [38]. Sel hepar yang mengalami nekrosis sedang atau kerusakan matriks ekstrasel akan tergantikan dengan sel normal dengan regenerasi dari sel yang masih hidup atau dari stem sel [39]. Dengan demikian, maka konsentrasi enzim $\alpha$-GST akan meningkat seiring dengan terbentuknya sel normal baru dan merespon masih adanya baik senyawa eksogen elektrofil lemah maupun $\mathrm{CCl}_{4}$ akibat belum tereliminasi karena kematian sebagian sel hepar. Hal ini harus dengan kondisi bahwa puncak ketoksikan dari $\mathrm{CCl}_{4}$ dosis $1,5 \mathrm{~mL} / \mathrm{kgBB}$ tidak tepat atau kurang dari jam ke-24.

Selain kadar enzim $\alpha$-GST, kerusakan hepar tikus pada kelompok $\mathrm{CCl}_{4}$ dapat juga diamati secara gross patologi dengan berat relatif hepar. Berat relatif hepar tikus kelompok $\mathrm{CCl}_{4}$ pada jam ke-72 lebih tinggi secara signifikan $(P<0,05)$ dibanding kelompok lainnya. Hal ini diduga telah terjadi kerusakan hepar dalam bentuk steatosis, inflamasi, atau nekrosis sehingga berat hepar 
meningkat. Berat relatif hepar kelompok vitamin C juga cukup tinggi meskipun tidak setinggi pada kelompok $\mathrm{CCl}_{4}$. Kondisi tersebut dapat pula menjadi gambaran mengapa terjadi peningkatan konsentrasi enzim $\alpha$-GST kelompok tersebut pada jam ke-72.

Ketoksikan $\mathrm{CCl}_{4}$ dosis $1,5 \mathrm{~mL} / \mathrm{kgBB}$ pada tikus Sprague-Dawley betina ini juga dapat dideteksi menggunakan konsentrasi enzim $\alpha$-GST darah. Konsentrasi enzim $\alpha$-GST kelompok $\mathrm{CCl}_{4}$ pada jam ke-0 atau beberapa saat setelah paparan $\mathrm{CCl}_{4}$ lebih tinggi secara signifikan $(P<0,05)$ dibandingkan pada jam ke-24 dan jam ke-72. Hal tersebut menunjukkan bahwa ketoksikan $\mathrm{CCl}_{4}$ dosis $1,5 \mathrm{mg} / \mathrm{kgBB}$ kemungkinan berada pada sebelum jam ke-24. Menurut Janakat dan Al-Merie [37], ketoksikan $\mathrm{CCl}_{4}$ dapat meningkat secara nyata dalam 2 jam pertama setelah pemaparan $\mathrm{CCl}_{4}$ dan maksimum terjadi puncak yaitu 24 jam setelah pemaparan.

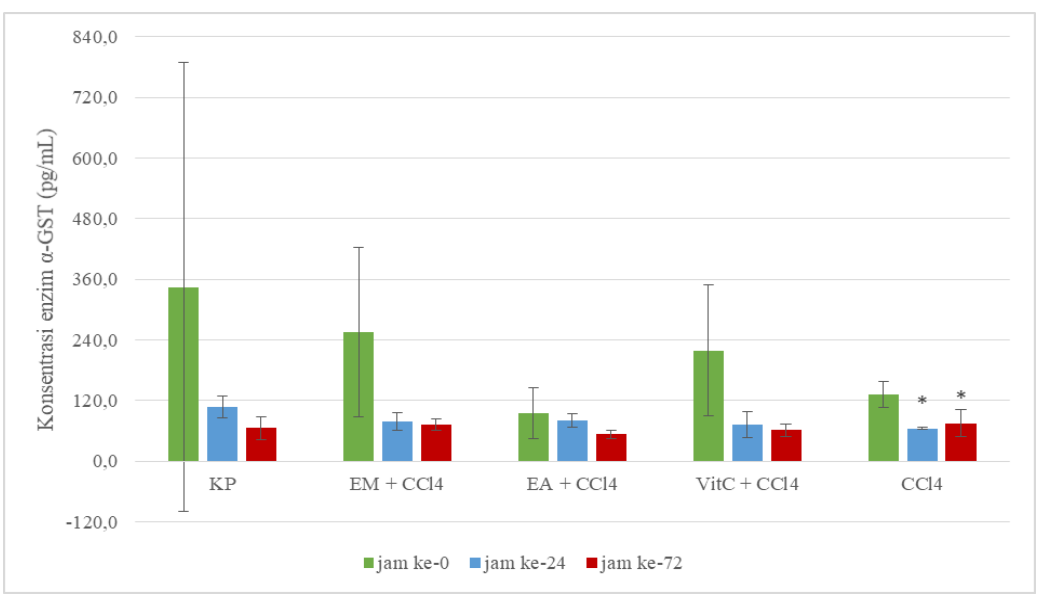

Gambar 5. Konsentrasi Enzim $\alpha$-GST darah tikus (tiap kelompok $n=3$ ). Keterangan: *) berbeda signifikan terhadap data jam ke-0

Analisis statistik menunjukkan bahwa tidak ada perbedaan signifikan konsentrasi enzim $\alpha$-GST darah tikus pada kelompok EM, EA, dan Vitamin C terhadap kelompok kontrol pelarut $(P>0,05)$. Pada Gambar 5 dapat dilihat bahwa kesamaan profil penurunan $\mathrm{CCl}_{4}$ antara keempat kelompok tersebut, terlihat pada jam ke-24 sampai jam ke-72. Hal yang berbeda terlihat pada kelompok $\mathrm{CCl}_{4}$ dimana konsentrasi enzim $\alpha$-GST mengalami peningkatan dari jam ke-24 sampai jam ke-72.

Profil penurunan $\alpha$-GST juga tampak pada data konsentrasi enzim $\alpha$-GST hepar tikus. Pemberian $\mathrm{CCl}_{4}$ justru akan memberikan profil peningkatan konsentrasi enzim $\alpha$-GST hepar dari jam ke-24 hingga jam ke-72. Konsentrasi enzim $\alpha$-GST hepar kelompok tikus EM dan EA mengalami penurunan sama dengan konsentrasi enzim $\alpha$-GST kelompok kontrol pelarut. Jika peningkatan konsentrasi enzim $\alpha$-GST pada kelompok kontrol $\mathrm{CCl}_{4}$ merupakan gambaran kerusakan sel hepar, maka dapat dikatakan bahwa ekstrak metanolik dan fraksi etil asetat mampu menjaga kerusakan sel hepar dengan menurunkan konsentrasi enzim $\alpha$-GST baik hepar maupun darah tikus. Hasil ini sesuai dengan hipotesis bahwa pemberian ekstrak metanolik dan fraksi etil asetat buah kepel dapat mencegah kerusakan akibat $\mathrm{CCl}_{4}$ serupa mekanisme aksi vitamin $\mathrm{C}$. 
Tabel 4. Korelasi konsentrasi enzim $\alpha$-GST hepar dan darah tikus pada jam ke-72

\begin{tabular}{|c|c|c|c|c|c|}
\hline & \multicolumn{2}{|c|}{ Kelompok Perlakuan } & \multirow[b]{2}{*}{$\begin{array}{l}\text { Fraksi Etil } \\
\text { Asetat }^{* *}\end{array}$} & \multirow[b]{2}{*}{ Vitamin $C^{*}$} & \multirow[b]{2}{*}{$\mathrm{CCl}_{4} *$} \\
\hline & $\begin{array}{l}\text { Kontrol } \\
\text { Pelarut* }\end{array}$ & $\begin{array}{l}\text { Ekstrak } \\
\text { Metanolik* }\end{array}$ & & & \\
\hline Korelasi & 0,997 & 0,855 & 0,816 & $-0,890$ & $-0,271$ \\
\hline Sig. (2-tailed) & 0,051 & 0,347 & 0,221 & 0,301 & 0,825 \\
\hline
\end{tabular}

Keterangan: *Pearson correlation; ${ }^{* *}$ Kendall's tau correlation

Berdasarkan data konsentrasi enzim $\alpha$-GST hepar dan darah tikus pada jam ke-72, tidak terdapat korelasi secara secara signifikan $(P<0,05)$ antara konsentrasi enzim $\alpha$-GST hepar dan darah (Tabel 4). Meskipun demikian, terdapat korelasi positif cukup kuat pada kelompok kontrol, kelompok EM, dan kelompok EA, hal ini dapat diartikan semakin tinggi konsentrasi enzim $\alpha$-GST hepar maka semakin tinggi pula enzim $\alpha$-GST dalam darah. Pada kelompok vitamin $\mathrm{C}$ dan $\mathrm{CCl}_{4}$, terdapat korelasi negatif namun tidak signifikan yang berarti bahwa konsentrasi enzim $\alpha$-GST hepar berbanding terbalik dengan konsentrasi enzim $\alpha$-GST darah.

\section{KESIMPULAN}

Ekstrak metanolik dan fraksi etil asetat buah kepel terdapat senyawa flavonoid. Ekstrak metanolik dan fraksi etil asetat berpengaruh menurunkan enzim enzim $\alpha$-GST di hepar maupun darah tikus serta dapat mencegah kerusakan sel hepar tikus yang terinduksi $\mathrm{CCl}_{4}$.

Ucapan terima kasih: Penulis mengucapkan terima kasih yang sebesar-besarnya kepada Kementerian Riset dan Teknologi serta Kementerian Pendidikan dan kebudayaan yang telah membiayai penelitian ini melalui skema World Class Research 2020.

\section{Referensi}

1. Valko, M.; Rhodes, C. J.; Moncol, J.; Izakovic, M.; Mazur, M. Free radicals, metals and antioxidants in oxidative stress-induced cancer. Chem Biol Interact. 2006. 160, 1-40.

2. Droge, W. Free radicals in the physiological control of cell function, Review. Physiol Rev. 2002. 82, 47-95.

3. Tisnadjaja, D.; Edward, S.; Silvia; Partomuan, S. Pengkajian Burahol (Stelechocarpus burahol (Blume) Hook \& Thomson) sebagai Buah yang Memiliki Kandungan Senyawa Antioksidan. Biodiversitas. 2006. 7, 2, 199-202.

4. Pham-Huy, L. A.; He, H.; Pham-Huy, C. Free Radicals, Antioxidants in Disease and Health, Int J Biomed Sci. 2008. 4, 2, 89-96.

5. Gulcin, I.; Uguz, M. T.; Oktay, M.; Beydemir, S.; Kufrevioglu, O. I. Evaluation of the Antioxidant and Antimicrobial Activities of Clary Sage (Salvia sclarea L.). Turk I. Agric. For. 2004. 28, 25-33.

6. Soobrattee, M. A.; Neergheen, V. S.; Luximon-Ramma, A.; Aruoma, O. I.; Bahorun, T. Phenolics as potential antioxidant therapeutic agents: Mechanism and actions. Mutat Res. 2005. 579, 200-213.

7. Sumartini; Studi Aktivitas Antioksidan Senyawa Fenolik dalam Daging Buah Kepel (Stelechocarpus burahol); Tesis, Airlangga University Library; Surabaya, 2011.

8. Batubara, I.; Darusman, L.K.; Djauhari, E.; Mitsunaga, T. Potency of Kepel (Stelechocarpus burahol) as Cyclooxygenase-2 Inhibitor. The Journal of Indonesian Medicinal Plant. 2010. 3, 2, 110-114.

9. Cannell, R. J. P., Methods in Biotechnology, Volume 4: Natural Products Isolation; Humana Press Inc.; 
Totowa, 1999.

10. Wagner, G. J.; Hrazdina, G. Endoplasmic Reticulum as a Site of Phenylpropanoid and Flavonoid Metabolism in Hippeastrum. Plant Physiol. 1984. 74, 4, 901-906.

11. Singh, R. P.; Banerjeea, S.; Kumara, P. V. S.; Raveesha, K. A.; Rao, A. R. Tinospora Cordifolia Induces Enzymes of Carcinogen/Drug Metabolism and Antioxidant System, and Inhibits Lipid Peroxidation in Mice. J Food Chem. 2006. 13, 74-84.

12. Halim, S. Z.; Abdullah, N. R.; Afzan, A.; Abdul Rashid, B. A.; Jantan, I.; Ismail, Z. Acute toxicity study of Carica papaya leaf extract in Sprague Dawley rats. J Med Plant Res. 2010. 5, 1867-1872.

13. Fine Test. Instruction Manual: Rat $\alpha$-GST ( $\alpha$-Gluthatione S-Transferases) ELISA Kit; Wuhan Fine Biological Technology Co., Ltd.; Hubei, China, 2017.

14. Mirwan, A.; Ariono, D. Dinamika Tetes Ekstraksi Cair-cair dalam Kolom Isian dan Tanpa Isian; Prosiding Seminar Nasional Teknik Kimia Indonesia; Bandung, 2009.

15. Spigno, G.; Tramelli, L.; De Faveri, D. M.; Effects of extraction time, temperature and solvent on concentration and antioxidant activity of grape marc phenolics. J Food Eng. 2007. 81, 200-208.

16. Taubock, K. The Reduction Products of Flavonols with Boric. Acid and Organic Acids and Their Importance for the Fixation of Boron in Plants. Naturwiss. 1942. 30, 439.

17. Jones, W. P.; Kinghorn, A. D. Extraction of Plant Secondary Metabolites, dalam Sarker, S.D., Latif, Z., Gray, A.I., (Eds), Natural Products Isolation, 2nd Edition, 323-352; Humana Press, New Jersey, 2006.

18. Pramono, S. Bahan Ajar Galenika, 22; Fakultas Farmasi Universitas Gadjah Mada; Yogyakarta, 2012.

19. Uemitsu, N.; Nakayoshi, H. Evaluation of Liver Weight Changes following a Single Oral Administration of Carbon Tetrachloride in Rats. Toxicol Appl Pharmacol. 1984. 75, 1-7.

20. Helaly, G. F.; Mahmoud, M. M. Diagnostic value of alphaglutathione S-transferase as a sensitive marker of increased risk for hepatocellular damage in hepatitis $\mathrm{C}$ virus $(\mathrm{HCV})$ infection: relation to HCV viraemia. J Egypt Public Health Assoc. 2003. 78, 3-4, 209-223.

21. Mazur, W.; Gonciarz, M.; Kajdy, M.; Mazurek, U.; Jurzak, M.; Wilczok, T.; Gonciarz, Z. Blood serum glutathione alpha s-transferase (alpha GST) activity during antiviral therapy in patients with chronic hepatitis C. Med Sci Monit. 2003. 9, 3, 44-48.

22. Natarajan, S.; Remick, D. G.; The ELISA Standard Save: Calculation of sample concentrations in assays with a failed standard curve. J Immunol Methods. 2008. 336, 242-245.

23. Cox, K. L.; Devanarayan, V.; Kriauciunas, A. Immunoassay Methods, dalam Sittampalam, G.S., Coussens, N. P., Brimacombe, K., et al., (eds), Assay Guidance Manual, Bethesda (MD): Eli Lilly $\mathcal{E}$ Company and the National Center for Advancing Translational Sciences; Bethesda, Maryland, 2014.

24. Higgins, L. G.; Hayes, J. D.; Mechanisms of induction of cytosolic and microsomal glutathione transferase (GST) genes by xenobiotics and pro-inflammatory agents. Drug Metab Rev. 2011. 43, 2, 92-137.

25. Elbekai, R. H.; Duke, J.; El-Kadi, A. O. S. Ascorbic acid differentially modulates the induction of heme oxygenase-1, NAD $(\mathrm{P}) \mathrm{H}$ : quinone oxidoreductase 1 and glutathione S-transferase Ya by As3+, Cd2+, and Cr6+. Cancer Lett. 2007. 246, 54-62.

26. Kumar, S.; Pandey A. K. Chemistry and Biological Activities of Flavonoids: An Overview, Sci World J. 2013. 2013, 1-16.

27. Gopi, S.; Vadde, R.; Setty, O. H. Protective effect of aqueous extract of Phyllanthus fraternus against bromobenzene induced changes on cytosolic glutathione S-transferase isozymes in rat liver. Biochem Biophys Rep. 2017. 10, 208-214. 
28. Apati, P.; Houghton, P. J.; Kite, G.; Steventon, G. B.; Kery, A. In-vitro effect of flavonoids from Solidago canadensis extract on glutathione S-transferase. J Pharm Pharmacol. 2006. 58, 2, 251-256.

29. Ramiro-Puig, E.; Urpí-Sardà, M.; Pérez-Cano, F. J.; Franch, A.; Castellote, C.; Andrés-Lacueva, C.; et al. Cocoa-enriched diet enhances antioxidant enzyme activity and modulates lymphocyte composition in thymus from young rats. J Agric Food Chem. 2007. 55, 6431-6438.

30. Iskender, H.; Yenice, G.; Dokumacioglu, E.; Kaynar, O.; Hayirli, A.; Kaya, A.; The Effects of Dietary Flavonoid Supplementation on the Antioxidant Status of Laying Hens. Braz J Poultry Sci. 2016. 18, 4, 663-668.

31. Innova Biosciences. Guide to Enzyme Unit Definitions and Assay Design; Innova Biosciences Ltd. Babraham research Campus; Cambridge, 2017.

32. Haima, P.; Shaw, M. Novel Liver and Kidney Biomarkers for Improved Drug Safety Testing; TECOmedical Clinical \& Technical Review, TECOmedical Group; Swiss, 2014.

33. Boll, M.; Weber, L. W. D.; Becker, E.; Stampfl, A. Mechanism of Carbon Tetrachloride-Induced Hepatotoxicity.Hepatocellular Damage by Reactive Carbon Tetrachloride Metabolites. Z. Naturforsch. 2001. 56, 649-659.

34. Singh, A.; Bhat, T. K.; Sharma, O. P. Clinical Biochemistry of Hepatotoxicity. J Clin Toxicol. 2011. 4, $1-19$.

35. Ma, J. Q.; Ding, J.; Zhang, L.; Liu, C. Hepatoprotective properties of sesamin against $\mathrm{CCl}_{4}$ induced oxidative stress-mediated apoptosis in mice via JNK pathway. Food Chem Toxicol. 2013. 64, 41-48.

36. Clarke, H.; Egan, D. A.; Heffernan, M.; Doyle, S.; Byrne, C.; Kilty, C.; Ryan, M. P. $\alpha$-gluthatione s-transferase $(\alpha$-GST) release, an early indicator of carbon tetrachloride hepatotoxicity in the rat. Hum Exp Toxicol. 1997. 16, 154-157.

37. Janakat, S.; Al-Merie, H. Optimization of the dose and route of injection, and characterisation of the time course of carbon tetrachloride-induced hepatotoxicity in the rat. J Pharmacol Toxicol Methods. 2003. $48,41-44$.

38. Fausto, N. Liver Regeneration, J Hepatol. 2000. 32, 19-31.

39. Ramadori, G.; Moriconi, F.; Malik, I.; Dudas, J. Physiology and Pathophysiology of Liver Inflamation, Damage, and Repair. J Physiol Pharmacol. 2008. 59, 1, 107-117.

(C) 2020 by the authors. Submitted for possible open access publication under the terms and conditions of the Creative Commons Attribution (CC BY) license (http://creativecommons.org/licenses/by/4.0/). 